Mark WeEden

\title{
Hittite Scribal Schools Outside of Hattusa?
}

\begin{abstract}
The article investigates the meagre textual evidence for Hittite scribal schools outside of Hattusa against the background of new excavations and the questions they raise about the social context of Hittite cuneiform writing. The use of the term é.dub.ba(.a) in Late Bronze Age Anatolia by contrast to Middle Bronze Age Babylonia is briefly touched on, and the institution of the É GIš.KIN.TI at Karahna is compared with that at Hattusa*.
\end{abstract}

Keywords: Scribal school, Boğazköy, Ortaköy, Maşat, social context of cuneiform writing, temple.

\section{Cuneiform among the Hittites}

Only in recent years has the study of Hittite school institutions and programs begun to gain momentum. Special mention should be given to the studies of Giulia Torri concerning the distribution of text-types and writing personnel recorded on tablets in the lower-city at Hattusa, especially the Haus am Hang, and also to those of Shai Gordin, investigating the prosopographical relationships between individual scribes and the possible institutional frameworks for such relationships. In these cases the focus has thus far been on the Haus am Hang and the possible É GIŠ.KIN.TI in the Südareal south of Temple I, which have both been held to have been scribal schools or scriptoria within the city of Hattusa ${ }^{1}$.

At the same time the text-finds from sites other than Boğazköy are beginning to multiply, prompting consideration of the social and geographic distribution of Hittite cuneiform writing in Anatolia, although this must be said to be a process that is in its infancy due to the current state of finds and/or publication. In the following I would like to consider evidence for Hittite scribal schools outside of Hattusa. It has to be said that there is currently not much published evidence, but it is not too early to begin the discussion. I will consider direct references to scribal institutions as they are found in available cuneiform texts, and I will concentrate on the texts of the central Anatolian area, as these

\footnotetext{
* The article has benefited from comments gratefully received from Joost Hazenbos and Jared Miller of the editorial board at $A o F$.

1 Torri (2008; 2009); Gordin (2010;2011).
} 
present a unified whole, with strikingly uniform sign-forms and regularity of sign-values. So unified is the script of finds of Hittite texts from outside Boğazköy in central Anatolia, that one might assume a centralised education in writing.

Hittite texts from Syrian centres such as Alalakh ${ }^{2}, \mathrm{Emar}^{3}$ and Ugarit ${ }^{4} \mathrm{~L}_{\text {uently }}$ present anomalies in orthography, phonotactics and script which are not to be found in texts from the Central Anatolian Area, oddities which may in large part be due to the influence of local scribal traditions, possibly dominated from the Hittite chancellery at Karkamiš. This also applies to the Sammeltafel of texts "made in the manner of Arusna", that Jared Miller has recently presented at two conferences ${ }^{5}$. It displays numerous orthographic peculiarities not otherwise found at Hattusa, some of which may be explained as being the result of school traditions closer to those found in Syria ${ }^{6}$. Much further research is needed on this topic.

It can be argued that a fundamental sociological difference exists between the Hittite use of cuneiform and that of neighbouring cultures in the Ancient Near East, most starkly, although slightly artificially, when compared with the social context of writing during the Old Babylonian period in Mesopotamia 7 . While Old Babylonian cuneiform writing was to an extent at least embedded into city life, with schools at Nippur and Ur apparently being held in private houses, or teaching being done in the student's own home, Hittite cuneiform writing tended to be a state affair. Here we have learned to be very careful when talking about public versus private institutions in the ancient world, certainly for the Old Babylonian period it is frequently not a distinction that makes a great deal of sense.

However, the temple and palace archival context of Hittite cuneiform from Hattusa stands in marl ntrast to the domestic urban context of Old Babylonian Mesopotamia. This anomaly 2 aralleled by the types of texts available (figure 1), the lack of economic texts in Hittite cuneiform representing a contrast to the relatively widespread finds of economic documents in family domestic contexts in Babylonia. Hittite cuneiform, in the archives that have come down to us, is inextricably tied to the needs and survival of the extended royal family that constituted the Hittite ruling class. This finds expression in the types of texts written and archivised: rituals, festivals, omens, diplomatic texts, literature.

The aristocratic bias also finds expression in the geographical distribution of the places where we find Hittite cuneiform. Hittite cuneiform appears in those places which were of

${ }^{2}$ See O. R. Gurney's suggestion of a local Hittite scribal style at Alalakh (AIT 454) apud Wiseman (1953: 117-118). The most striking grounds for this suggestion are the use of the sign-value lì in a Hittite word (ha-lì-iš-ši-ir AlT 454 ii 19), unattested at Hattusa, and the writing a-li-liš-ia-an (ii 35) for usual a-al-li-ia-an. The palaeography of AlT 454 is entirely Boğazköy, however (Gurney loc. cit. 116). For further Hittite tablets from Alalakh, see Niedorf (2002); Hoffner (2009:372-374).

${ }_{3}^{3}$ For the Hittite tablet from Emar see Hoffner (2009:367-368).

4 Tablets written in Akkadian by Hittites found at Ugarit sometimes demonstrate elements of a specifically Hittite orthography beside certain Syrian sign-forms. See for example pí-ha-wa-al-ú-i with a typically Hittite spelling in RS 17.247 and 17.108 (Nougayrol 1956: 191, 165, 248); Hawkins apud Herbordt (2005:293-295).

5 Miller (2011); Miller forthcoming. I am grateful to the author for a pre-publication copy of this.

${ }^{6}$ Miller (forthcoming) draws attention to the use of lì, for example, which is also attested at Alalakh (see above, fn. 2).

7 Weeden (2011a:598-600). 


\begin{tabular}{|l|l|l|l|l|l|l|l|l|l|}
\hline & Boğazköy & Ortaköy & Kuşaklı & Maşat & Büyüknefes & Kayalıpınar & Tarsus & İnandik & Oymaağaç \\
\hline rituals & 3872 & $*$ & 1 & & & 3 & & & \\
\hline festivals & 6462 & $*$ & 21 & & 1 & 4 & & & 2 \\
\hline omens & 1571 & $*$ & 18 & 2 & & 1 & & & \\
\hline historical & 1455 & & 1 & 1 & & 1 & & & 1 \\
\hline letters & 461 & $*$ & 3 & 97 & & 2 & & & \\
\hline $\begin{array}{l}\text { literary/ } \\
\text { school }\end{array}$ & 1242 & $*$ & & 1 & & & & & \\
\hline $\begin{array}{l}\text { admin/ } \\
\text { legal }\end{array}$ & 827 & $*$ & 1 & 16 & & & & 1 & 1 \\
\hline economic & 1 & & & & & & & & \\
\hline
\end{tabular}

Fig. 1: Provisional breakdown of tablet fragments according to text-types at Hittite sites based on data from S. Košak, Konkordanz der hethitischen Texte, www.hethiter.net.

historical strategic importance to Hittite economic and military interests and which thus found themselves on the circuit of towns visited by the king during festivals ${ }^{8}$. We could almost make a rule: where we do not find royal seals, we do not find cuneiform writing. Maşathöyük ${ }^{9}$, Ortaköy ${ }^{10}$, Kuşakl1 ${ }^{11}$, Oymaağaç ${ }^{12}$, Kayalıpınar ${ }^{13}$, all yield seal-impressions if not of royalty then at least of officials close to royal circles. If Oymaağaç is Nerik, Kuşaklı is Sarissa, and Kayalıpınar is Samuha, then we know that Hittite kings visited these places. Where we do not find any evidence of Hittite cuneiform writing, Kaman-Kalehöyük for example, we do not find evidence of any royalty among names preserved on seal-impressions there $^{14}$. Of course this is a rule based on a silence that can only too easily be broken by the appearance of new evidence ${ }^{15}$.

${ }^{8}$ For the Nuntarriyasha festival see Nakamura (2002: 438); Barjamovic (2011: 62 fn. 185); for the AN.TAH.ŠUM ${ }^{\mathrm{S} A R}$ festival see Houwink ten Cate (2003); Schwemer (2004). More generally see Hazenbos (2003:191-199).

9 Alp (1991:Tafel 1-3).

10 A. Süel (2009: fig. 7, fig. 15) for Tabarna seal-impressions; ibid. fig. 9 and M. Süel (2008: 474) for a mould with royal design (Tudhaliya and Taduhepa); numerous excellently preserved seals of officials have also been found at $\mathrm{O}$

11 Müller-Karpe (2002: 335f. tablets of the Sarissa festivar(CIH 636), see Wilhelm (1995:39f.); Hawkins (2006).

12 At Oymağaaç/Nerik no royal seals have been found thus far, although a sometime royal presence is undeniable if the identity with Nerik is in fact correct, and cuneiform has most certainly been found there (Czichon 2009: Plate IV Abb. 13-14; van den Hout 2010: 265). A known official, Sarini, is attested on a seal-impression. See J. Klinger in Arbeitsberi 6.05 (Philologie), www.nerik.de.

13 Rieken (2009); Müller-Karpe (2009: Plates X-XI especially fi 257 ).

14 Yoshida (1999;2006); Weeden (2010); Kaman-Kalehöyük has yıeIded the largest cache of hieroglyphic seal-impressions outside Boğazköy. There are no royal seals among them. An Empire-period tripodal seal from Kaman-Kalehöyük attests the name Kumma/iyaziti, known from Boğazköy and Alalakh, although it is not clear if this is the same person; Yoshida (1994).

15 While we find royal seals of non-Hittite kings at Korucutepe (Güterbock 1973a), cuneiform writing was not found there, as L. d' Alfonso points out to me. Excavation was only conducted for three seasons, however. 
The recent (2010) excavation of a fragmentary cuneiform tablet dated to the $14^{\text {th }}$ century at Büklükale, $40 \mathrm{~km}$ to the north-east of Kaman-Kalehöyük on the western bend of the Kizll Irmak, is interesting in that it appears to be part of a royal letter. One would not expect Büklükale to have been on the king's festival circuit, so the appearance of a cuneiform tablet there might otherwise have weakened the view of Hittite cuneiform presented here ${ }^{16}$.

I realise that there are numerous problems with this model. Nini, the scribe of the donkey-house attested on a seal-impression from the Nişantepe corpus ${ }^{17}$, the "scribes on wood" attested in cuneiform documents, do they really fit into such a picture? This question becomes all the more acute given Th. van den Hout's recent interpretation of the "scribes on wood" as "clerks" 18 . Furthermore, a diachronic perspective provides us with a more differentiated picture. In the late Middle Hittite period the genre of letter-writing using cuneiform on clay appears to be far more widespread than it is in the Empire period. Dignitaries and officials of the Hittite state wrote to each other on a range of issues including personal ones, although these are usually restricted to the so-called piggy-back letters, or postscripta, which accompany the main letter ${ }^{19}$. However, I would maintain that the practice of writing even in these contexts is conditioned by the direct proximity of said individuals to royal circles and their engagement in military or civil activities with a broad royal mandate. This is doubtless a view of Hittite cuneiform that not everyone will accept, but it is important that I make it clear by way of preface to the following considerations ${ }^{20}$.

\section{A Scribal School at Ortaköy?}

The largest published find of cuneiform tablets outside of Hattusa is currently still that of Maşathöyük near Zile, plausibly identified with Hittite Tapikka ${ }^{21}$. The main find-spots are in rooms 8 and 9 of the citadel and the columned hall beside these, thus indicating that the tablets were probably kept on an upper floor from which they fell ${ }^{22}$. Little can be said about the distribution ${ }^{23}$. The majority of the administrative texts were found in room 8 and in the columned hall outside ${ }^{24}$. This is possibly enough to indicate that there was originally an order of some kind, but we are unlikely to ever know what it was.

That at least the notion of a scribal school was current to the Hittites is shown by the logographic terminology they chose to denote the instrument used to write cuneiform, the stylus. A tablet from Maşathöyük, the postscripted letter from the scribe Tarhunmiya to the

16 This tablet will be published by the excavator, K. Matsumura, in collaboration with the author.

17 Hawkins apud Herbordt (2005: 301, Kat. 634). "Scribe of the Stable Area" Hoffner (2009:10).

18 Van den Hout (2010).

19 Van den Hout (2003:145).

${ }^{20}$ Gordin $(2010$ : 160-161, 170) offers a potentially different view of the social context of cuneiform scribes.

21 Alp (1991).

22 Van den Hout (2007: 388); Hoffner (2009:43).

23 Van den Hout $(2007: 388,396)$.

24 Van den Hout (2007:389-390). 
scribe Uzzu asking him to send a writing stylus because his own is broken, uses a singular form of Sumerogram for this item:
HKM 71 left edge: (1) GI É.DUB.BA-mu-[k]án ḩar-ak-[t]a (2) nu-mu ŠEŠ.DÙG.GA-IA G[I] É.DUB.B[A] up-pí
"My stylus is broken, send me a stylus, my dear brother".

The usual Mesopotamian logogram for stylus is gi dub.ba, "reed of the tablet", rather than GI É.DUB.BA, "reed of the tablet-house", which makes this an intriguing Hittite misunderstanding 25 . Without the institution of the scribal school, it would have been difficult to make this mistake. Why Tarhunmiya, based in Hattusa or Sapinuwa, should ask Uzzu, based in Tapikka, to send him a stylus, is unclear. One might assume that Tarhunmiya has some sort of personalised stylus, indeed, probably made of metal, and that he was currently not in any of the other major cities, possibly being on a business trip with his superior, the GAL $^{\text {LÚ.MEŠ }} \check{I S}^{26}$. Potential bronze styluses have been found at Hattusa, although their precise mode of usage is disputed, and also at Ortaköy, where the stylus, if it is one, is made of $\operatorname{gold}^{27}$.

A silver stylus, again called a GI É TUP-PÍ, with a semi-Akkadographic writing of É.DUB.BA, is mentioned in the ritual for the ancient gods (CTH 492): GI É TUP-PÍ KÙ.BABBAR IŠ-[...] KUB 17.20 ii $25^{28}$. It is mentioned in a series of silver items that are to be placed in front of the statues of particular gods. Which god the stylus is to be placed before is not entirely clear ${ }^{29}$. Two lines before, there is also mention of a $L E-E H-E$ KÙ.BABBAR ZI.KIN.BAR [KÙ.BAB-

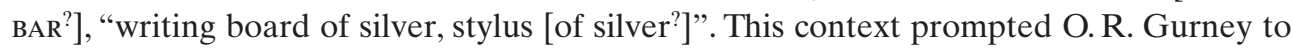
suggest the translation "stylus" for this attestation of Hittite sepikkusta/logographic ZI.KIN.BAR, otherwise usually translated as "pin", and I have further suggested that this may be the term for a hieroglyphic stylus as opposed to the cuneiform stylus that would here be the GI É TUP-PI ${ }^{30}$. If this is correct, not only do we have good evidence, both archaeological and philological, for the stylus made of metal among the Hittites, but it would also appear that the stylus specifically used for cuneiform was named after the institution where cuneiform was learned: the Edubba.

The one explicit mention of a writing school, using the typical Mesopotamian logogram for the institution in a strikingly archaic form, is attested on a tablet again probably found

25 Borger (2003: no. 141, p. 281).

${ }^{26}$ Marizza (2007: 87) contra Houwink ten Cate (1998:163).

27 A. Süel (2008: 465, 474 fig. 8), with the hypothesis that such a stylus was used for specifically writing ritual texts; A. Süel (2009: plate XXI fig. 10).

28 Waal (2010: 57). The $I \check{S}$-[ $[\ldots]$ may designate where the stylus comes from $(I \check{S}$-[TU]) or may come from the verb isgar- "to pierce", which is sometimes used to designate the manner in which an object has been offered up to a god, e.g. appan isgaran "pierced at the back", of a sun-disc which is presumably to be hung up, at KUB 42.78 iii 12 . See Taş and Weeden (2010:357-358 with fn. 37). The former possibility $(I \check{S}-[T U])$ I consider to be the more likely option.

${ }^{29}$ Depending on interpretation, it may be that they are to be placed before ${ }^{\mathrm{d}} \mathrm{KAL}$ (ibid. 26).

${ }^{30}$ Gurney (1940: 90); Beckman (1983a: 64); Weeden (2011b: 90 fn. 415). 
at Maşathöyük ${ }^{31}$. The letter is addressed from one Tarhuntissa to one Palla and contains the following sentence:

\begin{abstract}
ABoT 65 rev.
nu ha-an-da-a-an A-NA ${ }^{\mathrm{m}} A-T I-U-U N-N A$ I-NA É.DUB.BA.A (9) ki-iš-ša-an me-ma-ahhu-un A-BU-KA-wa-mu-uš-ša-an (10) EGIR-an-pát ki-it-ta-ri EGIR-an ar-ha-wa-raaš-mu (11) Ú-UL nam-ma ne-e-a-ri

"And I spoke thus directly to Atiunna in the Edubba: Your father is right behind me, he will not turn away from me, will he?"
\end{abstract}

The translation follows the spirit of H.C. Melchert's interpretation of appan=pat kittari, giving a positive rather than negative slant to the relationship between Atiunna's father and Tarhuntissa. This is contrary to all other translations, but the issue is of secondary importance for present purposes ${ }^{32}$. Important here is the clear use of É.DUB.BA.A as the location of a physical conversation.

Two questions need to be addressed here: i) what is this É.DUB.BA.A and ii) where is it? The question of where is answered most succinctly, if not completely securely. The tablet is supposed to have been found at Maşathöyük. This is slightly problematic, as the addressee is not otherwise known from the Maşat corpus. Clearly ABoT 65 was not sent from Hattusa, as the author makes clear:

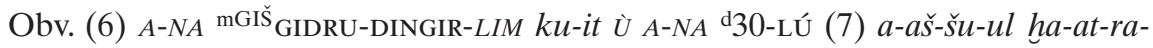

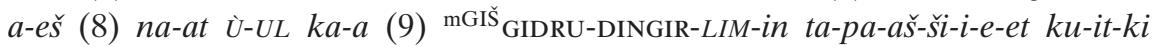
(10) nu URU ha-at-tu-ši pé-en-ni-iš

"As for the greeting-letter you wrote to Hattusili and to Armaziti, they are not here. Something tapassiya-ed Hattusili ${ }^{33}$ and he drove off to Hattusa."

Hattusili was an important official who may have been the GAL DUB.SAR ${ }^{\text {MEŠ }}$ otherwise known from Hattusa and from Maşat-correspondence ${ }^{34}$. F. Imparati has also argued that

31 For the rich literature on this tablet see Marizza (2007: 120 fn. 8); Hoffner (2009: 242).

32 Melchert (1979: 60); the alternative translation, which puts a negative slant on this phrase (e.g. folgt mich" Rost 1956:347) is primarily argued on the basis of the occurrence of the idiom appart=pat kittat in KUB 14.1 obv. 1-2, where it denotes the clearly hostile activity of Attarissiya towards Madduwatta. See CHD P 144; Hoffner (2009: 386 fn. 193) "keeps after me". This evidence and the consensus that has grown about it (additionally Güterbock 1944: 400; Hagenbuchner 1989: 176; Houwink ten Cate 1998: 175-176) is impressive. The only difference between the phrase in Madduwatta and the phrase here, apart from the tense, is the use of the particle -kan (KUB 14.1 obv. 1) as opposed to -san. It is possible, however, that "lying behind" someone could have both a positive and a negative implication. Note the entirely positive appan tiya- "stand behind, support".

33 This verb is plausibly interpreted as a word describing illness, e. g. "fever", taking the accusative of the person who is ill; Houwink ten Cate (1998: 176 fn. 22); Hoffner (2009: 245). That a fever should be grounds for undertaking a three day journey from Ortaköy (see below) to Hattusa is unlikely, however.

34 Beckman (1995: 25); Houwink ten Cate (1998: 158); de Martino (2005: 311); Marizza (2007: 119-127) for a thorough, cautious but inconclusive appraisal of the evidence that the high official Hattusili of this period is to be identified with the contemporary GAL DUB.SAR ${ }^{\text {MEŠ }}$. For a different tentative identification see Klinger (1995: 90). 
letters from Maşat in which Hattusili and others refer to the "Palace" (É.GAL-LIM) most probably mean Ortaköy-Sapinuwa, the regional seat of government or temporary capital ${ }^{35}$. This makes it very likely that the "here" in ABoT 65 obv. 6 referred to Ortaköy-Sapinuwa as the origin of the letter. I would also assume that this means that the conversation referred to in the Edubba would have occurred in the place that Tarhuntissa is writing from ${ }^{36}$.

Several of the Maşat-letters were most likely sent from Ortaköy-Sapinuwa, especially those written by Piyama-Tarhu, a scribe known from Ortaköy, or those sent by Sarpa, a scribe who appears to be operating from Sapinuwa according to evidence from Maşat ${ }^{37}$. Furthermore there is evidence from the excavations at Ortaköy that the "Chief Scribe", although unnamed, both sent letters to scribes at Ortaköy, including to the aforementioned Piyama-Tarhu, and himself received letters there from elsewhere ${ }^{38}$. This fits perfectly with the activities of Hattusili attested in ABoT 65: he would be moving between Sapinuwa and Hattusa.

\section{What Kind of School?}

That there should have been a physical scribal school known as the É.DUB.BA.A in $14^{\text {th }}$ century Anatolia is surprising in the first place. Recent research has tended to the opinion that the typical Edubba-school of Mesopotamia only existed in the Ur III period, while the Old Babylonian textual attestations of such places, in the so-called Edubba-texts, which include descriptions of life in an extensive school-type institution, exclusively refer to a semimythologised literary construct of an age long-gone ${ }^{39}$. This conclusion is based on the archaeological contexts of buildings containing school-texts in Mesopotamia: the House F in Nippur area TA and the House of Ur-Utu at Sippar-Amnanum ${ }^{40}$, which are clearly family dwelling places as opposed to larger communal institutions. A house associated with scribal education at $\mathrm{Ur}$ is also domestic, but its inhabitants were apparently connected to the nearby temple of Nanna, the Ekišnugal ${ }^{41}$. What is this É.DUB.BA.A doing here in early $14^{\text {th }}$ century Anatolia? ${ }^{42}$

In fact, at least one Old Babylonian letter does refer to an É.DUB.BA.A as a concrete space. The OB letter AbB 3.84, from the Lagaba collection, makes it clear that teaching in the OB period could take place in the student's home, or more precisely their parent's home, while

35 Imparati (1997:201-205).

36 Beckman (1983b: 97 fn. 2) assumes the opposite from this attestation: the Edubba was in Hattusa. This implicitly assumes that there could only be one Edubba.

37 For Piyama-Tarhu at Ortaköy see A. Süel (2008: 464); for Sarpa in Sapinuwa see Alp (1991: 92); he is not mentioned in connection with Ortaköy in A. Süel (1995); also Houwink ten Cate (1998: 174, with caution in fn. 21).

38 Süel (2008: 464).

39 George (2005).

40 Robson (2001); Tanret (2002).

41 Charpin (1986:27-92, esp. p. 42). Further Volk (2000:5-7).

42 Compare for example the view that the rare mentions of the Edubba'a after the OB period are "nicht mehr als Reminiszenzen an eine vergangene Epoche"; Volk (2000: 4). 
testing took place somewhere called the É.DUB.BA. $\mathrm{A}^{43}$. This may well have been an as yet unexcavated communal school. However, it is just as likely on the albeit meagre basis of the archaeology of OB schools, that É.DUB.BA.A in this text refers to the teacher's house, designated as an Edubba as a term of deference ${ }^{44}$.

In the case of the Hittite attestation we have further to be aware that there may have been confusion between the writing É.DUB.BA.A and the otherwise attested é tuppas, which H. Otten has argued to be an administrative institution ${ }^{45}$. The problems inherent in the uses of these similar terms are well illustrated by the dilemma posed in the only other attestation known to me in Hittite texts of the logogram É.DUB.BA referring to a place.

An offering list from the AN.TAH.ŠUM ${ }^{\text {SAR }}$ festival refers to offerings to be made "to the stag-god (protective deity) of the king and to the (divine) throne of the É.DUB.BA" ${ }^{46}$. It is possible that the mention of these two divinities together indicates that we are dealing here with an É.DUB.BA on Büyükkale, the royal citadel itself. The tablet is written in the latest form of Hittite cuneiform, NSc, and is thus to be dated to the $13^{\text {th }}$ century, although the material treated within it, as well as aspects of the language, can be assumed to go back to Old Hittite traditions ${ }^{47}$. One cannot exclude, however, that É tuppas, "magazine", is meant here. The writing with BA and not PA, as well as the position of the enclitic connective $=a$ may speak against this, but É tuppas appears to be how the fragment of a duplicate manuscript understood the text ${ }^{48}$. The identification of a royal É.DUB.BA on Büyükkale on the basis of this text alone is thus dubious ${ }^{49}$.

However, although we should be careful to admit the possibility of mistakes in the use of logograms by Hittite scribes, it is reasonably safe to say that the É.DUB.BA.A in ABoT 65 is in fact a scribal school. The writing with the extra A is typical for this Sumerian word in Mesopotamia $^{50}$. Two of the Mesopotamian school exercises known as Edubba-texts are also known from Hattusa inscribed on prisms, at least one of which has been thought to be an import, although this is hard to tell without collation ${ }^{51}$.

The reference to "your father" in ABoT 65 has been interpreted as a reference to the master of the scribal school ${ }^{52}$. It is frequently assumed that teacher-pupil relationships are expressed in Hittite by familial terms, just as they were frequently in Old Babylonian Mesopotamia $^{53}$. Houwink ten Cate saw $A B \bar{U}=K A$ as a reference to Hattusili, the Chief

43 AbB 3.84: 6-16 concern instruction in writing in the parental home; ibid. 18-23 concern testing in the Edubba. See Weeden (2011a:599).

44 Weeden (2011a: 599-600). For further OB examples of teaching at home, see Volk (2000: $8 \mathrm{fn}$. 41). This is not to say that teaching in the OB period was not conducted in temples and palaces - see Volk loc. cit. 6 fnn. 28,29, but they don't appear to have been specially constructed schools.

45 Otten (1988: 40); van den Hout (2010: 266-267).

${ }^{46} \mathrm{KBo} 4.13$ obv. ii 14: $A-N A{ }^{\mathrm{d}} \mathrm{K}[\mathrm{A}] \mathrm{L}$ LUGAL É.DUB.BA-ašša ${ }^{\mathrm{d}}$ DAG- $t i$, normalised with one ŠA too many at Archi 1966: 99.

${ }^{47}$ Cursorily Melchert (1977: 82).

${ }^{48} \mathrm{KBo} 45.27$ obv. 7: [É tup-]pa-aš-ša GIŠ

${ }^{49}$ For further evidence of scribal practice on Büyükkale, see S. Gordin's contribution to this volume.

50 Volk (2000:3).

51 Weeden (2011b: 83 fn. 384).

52 Tentatively Hoffner (2009: 245).

${ }^{53}$ Hoffner (2009:58-59). 
Scribe, who dominates the narrative on the reverse of the tablet ${ }^{54}$. It may be possible to view the use of $A B \bar{U}=K A$ as a term of deference towards a teacher, although this would be unparalleled outside of greeting formulae ${ }^{55}$. However, if Tarhuntissa had wanted to refer to his own and Atiunna's teacher in the É.DUB.BA.A, he might have referred to him as $A B \bar{U}=N I$, "our father".

If Hattusili is in fact the father of Atiunna, both Atiunna and Tarhuntissa are having this conversation in the É.DUB.BA.A, which is either a communal institution or Hattusili's own residence at Ortaköy. Even if one assumes that Hattusili must have been primarily resident at Hattusa, it is quite possible that he may have had a second house in another town, or that the boundaries between domiciles and places of work in various towns will have been fluid for this important official. I would tend to the conclusion that this institution was in fact his abode in Ortaköy. Why else would the location of the conversation be discourse-relevant to the fact that Hattusili is Atiunna's father, if the É.DUB.BA.A is not also Hattusili's house?

\section{Scribes' Houses as Institutions}

The distribution of senders and recipients of the Maşat letters, including postscripta or so-called piggy-back letters, has been used by Th. van den Hout to demonstrate the tight archival and thus most likely chronological coherence of the Maşat epistolary corpus ${ }^{56}$. A specific breakdown of the distribution of the addressees of the postscripta is additionally useful, as it shows a distinct bias (figure 2). The status of Uzzu as the main scribe connected to the archive found at Maşat is shown by the fact that he receives far more of the so-called piggy-back letters than are received by any other individual, fifteen in total. These additional letters, written onto the ends usually of other people's letters, are particularly revealing. If someone wanted to write to Uzzu, it is clear that they would find him by appending a post-script to a letter to someone in Maşat. In the cases of other officials, particularly those higher-ranking, such as Himuili, it is clear that they were frequently away, although Himuili himself receives the second largest share of postscripta. It is also interesting that Tarhunmiya writes five of these postscripta, again more than anyone else.

We know that Tarhunmiya had a house in Maşat, as several letters attest to the damage being done to it in his absence by the locals, a correspondence sometimes referred to as the "Tarhunmiya Affair" 57 . Apparently the local administration is imposing sahhan and luzzi taxes on the property, people are using his chariot and breaking it, things are not going well. Hattusili the chief scribe (?) takes Tarhunmiya's side and writes to the ${ }^{L} U_{B E} L M A D$ GALTI at Maşat, Himuili. The way he refers to Tarhunmiya's house is intriguing (HKM 52):

\footnotetext{
54 Houwink ten Cate (1998: 176).

55 Hoffner (2009:245).

56 Van den Hout (2007:391).

57 Van den Hout (2003).
} 


\begin{tabular}{|c|c|c|c|c|c|c|c|c|c|c|c|}
\hline From & To Uzzu & Kassu & Zilapiya & Hulla & Pulli & Himulli & $\begin{array}{l}\text { Bēl } \\
\text { madgalti }\end{array}$ & Walwanu & Adadbēli & $\begin{array}{l}\text { Pallanna } \\
+ \text { Manni }\end{array}$ & Unknown \\
\hline Surhili & $\begin{array}{l}2 \\
3\end{array}$ & & & & & & & & & & \\
\hline Hasammili & $\begin{array}{l}17 \\
19 \\
30\end{array}$ & 17 & 17 & 17 & & 36 & & & & & \\
\hline Piseni & & 18 & & & 18 & & & & & & \\
\hline Sanda & 21 & & & & & & & & & & \\
\hline Mār-ešrē & $\begin{array}{l}22 \\
31 \\
33 \\
53 \\
73\end{array}$ & & & & & & & & & & 82 \\
\hline Hattusili & $80 ?$ & & & & & $\begin{array}{l}27 \\
28\end{array}$ & & & & & \\
\hline Tarhunmiya & $\begin{array}{l}71 \\
81\end{array}$ & & & & & 52 & 27 & 56 & 65 & 60 & \\
\hline Himuili & 39 & & & & & 29 & & & & & \\
\hline Ilukultī & & & & & & & & & 58 & & \\
\hline
\end{tabular}

Fig. 2: Breakdown of Postscripta on Maşat letters according to letter number in S. Alp (1991). Recipients on vertical axis, senders on horizontal.

(10) tu-ga-kán a-pí-ia ma-ni-ia-ah-hi-ia an-da (11) ŠA LÚ DUB.SAR 1 É-TUM-pát nu-ut-ták-kán [UR]U? -i (12) an-d[a] ta-ma-e-eš dam-mi-iš-ki!-iš-kán-zi (13) A-NA LÚ.MEŠ $^{\text {DUB.SAR }}{ }^{\mathrm{MES}}$ ša-ah-ha-an lu-uz-zi (14) a-pí-ia-ma-at ku-wa-at iš-ša-i

"In your administrative area there is only one scribe's house, and others in your [tow]n are doing damage. (Is there) sahhan and luzzi for scribes? So why is he paying it there?"

This sounds as if Tarhunmiya's property is not only his personal residence, but also possibly an office of some kind, that it had a public function over and above being someone's personal property ${ }^{58}$. There is some dispute as to whether he is not supposed to pay taxes for this reason, i.e. because his house is a scribal house. Ph. Houwink ten Cate and Th. van den Hout suppose that his tax-exemrs due to his having a house elsewhere, in Hattusa. HKM 12, in which Tarhunmiya $\mathrm{m} 2 \mathrm{D}$ being arrested, is of questionable use as evidence in this connection ${ }^{59}$. The tablet is very broken, and the use of the verb $e-e[p]^{?}$, the reading of which is not clear following the traces copied by Alp, does not necessarily have to be an

58 Similarly Alp (1991: 96-98,333f.); Imparati (1997: 208); Hoffner (2009: 193-194); contra Houwink ten Cate (1998: 173); van den Hout (2003:151); id. (2007: 393 f. with fn. 36).

59 Van den Hout (2003: 153); Houwink ten Cate (1998:174) cautiously. 
order to arrest him. It could merely be an order to summon him, possibly in connection with this affair, or another, or even at the beginning of his service rather than at the end ${ }^{60}$.

A public function for the house connected with the scribal profession may explain why Uzzu send the writing-stylus from Maşat. Certainly, while he is away, the house appea 20 being used, which is part of the context for the law-suits and squabbles Tarhunmiya is involved in. Quite possibly the styluses that Tarhunmiya used were in his house, and one assumes that Uzzu had access to it. Is the house in fact being used as a scribal centre of some kind? This would also explain why the residences of other individuals, who were also patently scribes at Maşat, including Uzzu, would not have their residences referred to as "Scribe's Houses", if Hattusili says there is only one of these there.

A further piece of evidence concerning Tarhunmiya's house is contained in a postscript to a letter from the scribe Sarpa, who operated out of Sapinuwa, that is also concerned with the Tarhunmiya Affair. It is assumed that the postscript is from Tarhunmiya, even though he does not name himself, because his father is the addressee:

HBM 60:

(27) $A$-NA ${ }^{\mathrm{m}} P A L-L A-A N-N A A$-BI-DÙG.GA-IA (28) $\dot{U} A-N A{ }^{\mathrm{f}} M A-A N-N I-I$ (29) NIN.DÙG. GA-IA QÍ-BÍ-MA ... (34) aš-šu-ul-mu ha-at-re-eš-kat-tén (35) na[m]-ma-aš-ša-an $A$-BI-DÙG.GA-IA (36) A-NA É-IA IGI ${ }^{\mathrm{HI} . \mathrm{A}}-w a(37)$ har-ak

"To Pallanna, my dear father, and to Manni, my dear sister, speak ... write a greeting to me. Furthermore keep an eye on my house, dear father."

It is difficult to know what to conclude from this, whether Tarhunmiya's house is identical with his father's or whether it is a separate building. If the latter is the case it is possibly relevant that Tarhunmiya's father does not seem to have been able to read, as he needs a letter read out to him by $\mathrm{Uzzu}^{61}$. The paternal house would thus not necessarily be a "scribe's house".

Another use of the term "house of the scribe", found in a cult inventory text from Hattusa, may refer to a semi-public institution, at least a place for the storage of tablets:

[I-N]A É DUB.SAR EZEN ${ }_{4}{ }^{\text {MEŠ }}[\ldots]$ / Ú-UL ku-i-e-eš-qa KAR-u-en Bo. 3295 rev.? iii 6'.

"We did not find any festivals in the house of the scribe ..."

Tarhunmiya's residence at Maşat is unlikely to have been the central tablet storage facility, however, because the archive at Maşat is not found in a residential space. This may of course be an accident of discovery.

Thus far we have an É.DUB.BA.A which is possibly in Ortaköy and is either a communal building in a royal city or is a second residence of Hattusili the "chief scribe" which was

${ }^{60} \mathrm{HWb}^{2} \mathrm{E} 55$ lists peaceful attestations of $e p$ - with a human or divine object, albeit relatively few. The obscure injunction to the king of Ahhiyawa at KUB 14.3 iii 1 is possibly a friendly use of $e p$ - with regard to Piyamaradu, given the context that the Hittite king is trying to organise a rendez-vous with him: ŠEŠ-IA- $\ulcorner a n-z a\urcorner$-an ha-an-za $\ulcorner e\urcorner$-ep. Sommer 1930: 13.

${ }^{61}$ HKM 81, 29-30. The demand that the parents "write back" to him in $11.30-32$ is presumably to be executed by Uzzu at dictation. 
used as a school, and we have a scribe's house in Maşat, which may have been used in a public function which guaranteed it tax-exemption.

The location of an É.DUB.BA.A at Ortaköy is not surprising, given that tablets have been found there in Hattic and Hurrian alongside the fragments of lexical lists, such as the piece of Ura $17^{62}$. I have argued that this fragment fits well into the rest of the tradition of Ura otherwise found at Hattusa, not only from its ductus, but also from the perspective of the development of the list that it attests to, corresponding quite well to the Late Old Babylonian version, but also sharing innovative features with the first millennium version ${ }^{63}$. It also appears to indicate a stage before the use of separate columns for the Sumerian and Akkadian translations, these being separated only by a Glossenkeil. It does have Hittite translations in a separate column. We should note however, that this is unlikely to have been a school exercise tablet and cannot thus be used as direct evidence of school activity.

The scribal situation at Maşat deserves further comment due to the number of scribes attested there with Babylonian names: Adad-bēlī, Ilu-tukultī, Mār-ešrē. Whether these were actually Babylonian scribes, or Hittite scribes affecting Babylonian names, is unclear ${ }^{64}$. In the case of Adad-bēli at least, this is a scribe who communicates with the king himself directly. Mār-ešre is also close to royal circles. A scribe at Maşat with the Hittite name $\mathrm{Z} \bar{u}$ is asked by Hattusili the Chief Scribe to write back to him on a particular subject in Babylonian, either so that Kassu, the addressee of the main letter, did not understand the reply, or so that Zī might practise his Akkadian ${ }^{65}$. Maşat letters also contain some evidence that Akkadograms were actually read in Akkadian: BE-LU-uš-ša-an (HKM 52, 25 and HKM 80,5), for example, may indicate a pronunciation of an Akkadogram in Akkadian due to requiring the sign $-u \check{s}$ - to preface the Hittite particle $-s a n^{66}$. There are unusual writings of Akkadian words or Akkadograms such as AR-KI (HKM 106, 4; 107,13) EGIR-KI

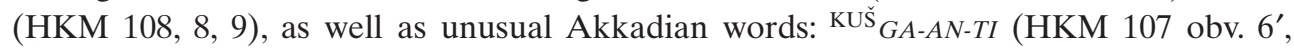
rev. $\left.12^{\prime}\right)^{67}, \check{S}$ I-E-ŠAR-RU (HKM 108,6$)^{68}$. Clearly Akkadian as the language of scholarship was flourishing at this small provincial centre.

62 Hattic: Süel and Soysal (2007); Ura 17: Süel and Soysal (2003).

${ }^{63}$ Weeden (2011b:108-111).

${ }^{64}$ Alp (1998); Hoffner (2009: 92). The extraordinary colophon fragment KUB 4.37, in monumental Babylonian script, has a scribe with a Babylonian name, Ilu-ublanni, writing under the supervision of a Hittite scribe (Zidi). Weeden (2011a: 602;2011b: 84 with fn. 393).

65 PA-BI-LA-Ú ha-at-ra-a-i (HKM 72,36).

${ }^{66}$ Scribe Tarhunmiya; Weeden (2011b:176). But see CHD P 276; Hoffner and Melchert (2008: 22 fn. 30); Hoffner (2009:384 fn. 154).

${ }^{67}$ Has been suggested to be Akkadian ${ }^{\text {dug }}$ kandu although this is only attested late (CAD K 148-149); del Monte (1995:119); considered unlikely at Weeden (2011b:321 fn. 1489).

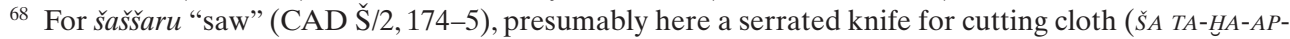

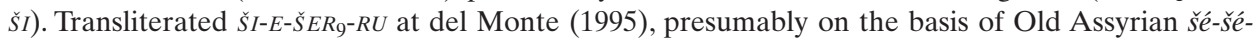
ru-um (RA 58.61, 21). Duld indicate specifically Assyrian influence, by contrast to Babylonian šaššru. However, ŠER r value, and Hittite Akkadograms do at least occasionally write A for E/I, see UZU $\breve{S A-L I-D U}$ for slltu "afterbirth" (AHw. 1043, 1148; CHD Š/2, 279), if not the other way

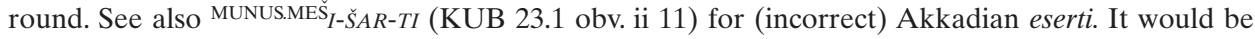
unwise to posit Assyrian influence on the Akkadian learned at Maşat solely on the basis of this form. 


\section{Scribal Schools Attached to the Temple?}

In Hattusa it has been variously proposed that the building referred to by excavators as the É GIŠ.KIN.TI in the area south of Temple I functioned as a scribal school in the late $13^{\text {th }}$ century ${ }^{69}$. The central reason for this proposal is the tablet KBo 19.28, which was found in a room of the complex south of the Great Temple, although a centimetre or so above the floor, detailing 205 DUMU ${ }^{\text {HI.A }}$ É GIŠ.KIN.TI, "members of the House of Craftspeople", including 18 priests, 29 katra-women, 19 scribes, 33 scribes on wood (or clerks?), 35 exorcists and 10 singers of Hurrian on its preserved surface ${ }^{70}$. Added to this we have the evidence of two officials called EN GIŠ.KIN.TI ("masters of the craftspeople") who are masters of apprentice scribes ${ }^{71}$.

Another É GIŠ.KIN.TI must have existed at Karahna, as its staff are mentioned in an inventory found at Hattusa detailing the cult of the stag-god of Karahna (CTH 517) ${ }^{72}$. The tablet in question, KUB 38.12, mentions the hilamatti-officials of the temple of ${ }^{\mathrm{d}} \mathrm{KAL}$ of Karahna. The word hilammatta- is usually translated as "temple personnel", being the people who are concerned with the courtyard, ${ }^{\text {E hila- }}{ }^{73}$, or more precisely with the É hilammar "gate-house or portico", that which leads on to the courtyard ${ }^{74}$. Here we appear to have an i-stem form, hilammatti- ${ }^{75}$. The functionaries associated with this temple are further divided up with slightly obscure designations ending with the statement that the officials "of the É GIŠ.KIN.TI are included for him (i.e. the god)":

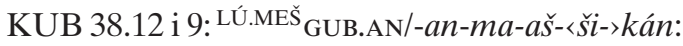

LÚ GIŠ ŠUKUR (“spearman”), LÚİ!.DU (“gatekeeper”), LÚ GIŠ BANŠUR (“butler”), LÚGALA ("lamentation-singer"), LÚpalwatallas ("clapper"), LÚarkammiyalas

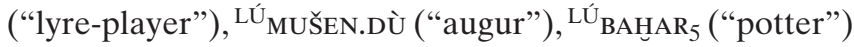

${ }^{69}$ Boehmer (1972: 197); Güterbock (1975:132); Gordin (2010: 159, 168-170); Weeden (2011b: 85-89).

70 CHD Š 196.

71 Zuwa and Miramuwa. See Gordin (2010:165f., $167 \mathrm{f}$.). The attestation of a similar title for Anuwanza on the basis of the broken colophon of KUB 30.26 (Gordin 2010:164) is unfortunately not verified by photo-collation (BoFN 0632a), as the head of the horizontal is a little too high for GIŠ, in my opinion. The reading should not be excluded on graphological grounds, however, as the writing of the horizontals does slope down to the right on this tablet. See however G. Torri in this volume.

72 CHD P 281 assumes the É GIŠ.KIN.TI here is referring to the one at Hattusa. As I see no reason for this assumption that is made explicit in the text, I assume that it refers to an institution in Karahna, whose temple of ${ }^{\mathrm{d}} \mathrm{KAL}$ is the subject of the inventory.

73 Puhvel (1991:307-308); Beal (1998: 86). For the latest bibliography see $\mathrm{HWb}^{2} \mathrm{H} 590$.

74 Rieken (1999:372); Kloekhorst (2008:342-343), although not explicitly.

75 I take all cases of (LÚ.MEŠ)hi-lam-ma-at-ti-eš in this text as representing hilammattis, nominative singular (collective), with the logical plural only being indicated by the plural determinative (i 3, 4, $6,17)$. Singular grammatical construal with numbers is usual in Hittite. Line i 5 clearly has the accusative $\left(9^{\mathrm{LU} . \mathrm{MES} h}\right.$ hi-lam-ma-at-tin $\left.\ldots p a-r a+a \mathrm{DAB}-i r\right)$, there is a singular predicate (DAB-an-za) in $\mathrm{i}$ 4,17 12 (sum-an-za) and a singular enclitic pronoun ( $n=a s)$ in i 6. LÚ.MEšh hi-lam-ma-tiš in ii 19

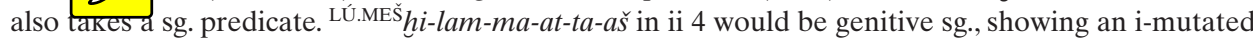
stem. Less securely sg. is the adjective an-na-al-li-eš in i 4 and iv 15. Either these are annallis or the congruence is inconclusive. Puhvel (1991: 307), Kloekhorst (2008: 342), CHD P 111, HWb ${ }^{2}$ H 590-591

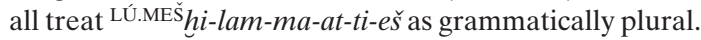




\section{$p a-r a+a$ DAB-ir}

"But they took out the (following) GUB(.AN)-officials 〈for him〉 (i.e. for the god) ..."

\section{KUB 38.12 i 11: ŠU.NÍGIN 26 hi-lam-ma-at-ti-eš š̀̀:}

1 LÚ GUDU $_{12}$ ("GUDU-priest"), 1 LÚ DUB.SAR ("scribe"), 1 LÚ DUB.SAR GIŠ ("scribe on wood"), 1 LÚ HaL ("exorcist"), 2 LÚ NAR ("singers"), 1 LÚ GIŠ BANŠUR ("table-man”), 1 LÚ MUHALDIM (“cook”), 2 LÚ SìlA.ŠU.DU

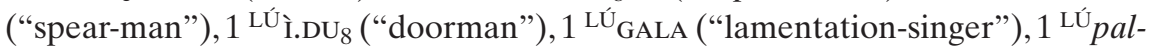
watallas ("clapper"?), 1 LÚarkammiyalas ("lyre-player"), 1 LÚ KÚRUN.NA ("brewer"), 2 LÚ NINDA.DÙ.DÙ ("bakers"), 1 LÚ A ŠA KUŠ.LÁ ("water-carrier") 76, 2 LÚ KISAL.LUH ("cleaners"), 1 LÚ MUŠEN.DÙ ("augur”), 1 LÚ BAHAR $_{5}$ ("potter") 1 LÚ E-PIŠ BA.BA.ZA (“porridge-maker”).

"(In) total (there are) 26 courtyard-officials, among whom:..."

KUB 38.12 i 17: LÚ.MEŠḩi-lam-ma-at-ti-eš LÚ.MEŠGUB.BA!-ḩa ŠA É GIŠ.KIN.TI-šikán (18) an-da DAB-an-za

"The courtyard and GUB.BA!(.HA?)-officials of the House of the Craftspeople have been included for him".

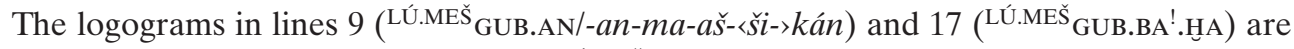
not otherwise attested ${ }^{77}$. The reading ${ }^{\text {LÚ.MEŠ }}$ GUB-an (acc. sg. of an a-stem word) could be made less likely by the fact that the nouns palwatallas and arkammiyalas appear in the nominative singular. This is, however, most likely a reflex of list grammar, possibly import-

76 Transliterated LÚA.ÍL'.LÁ at Weeden (2011b: 88), see HLZ 161 following Güterbock (1973b: 85f.). In view of the further attestations of LÚMEŠ A ${ }^{\prime} A$ KUŠ.LÁ (Weeden 2011b:556), the writing should probably not be corrected. Furthermore, my reading of the logogram in KUB 18.16 ii 1 as LÚA.íL'.LA'-wa (Weeden 2011b: 556) should be corrected to LÚ A ŠA KUŠ-wa. The Sumerogram appears to have been reinterpreted by the Hittite scribes.

77 One might compare the equally obscure professional designation in hieroglyphic CRUS(?) on two Nişantepe seal-impressions, which, if correctly identified in the first place, is either ideographic or contains the syllable $a r$ - (from $a r_{-}$-tari "to stand" or $a r$ - ${ }^{h i}$ "to come"). See Hawkins apud Herbordt (2005: 302). In one case (Kat. 549) the sign CRUS appears in combination with $\mathrm{AVIS}_{3}$ (L. 135.2), a possible equivalent to the LÚMUŠEn.DÙ, "augur" (Hawkins apud Herbordt loc. cit.; for another possible combination of offices see Weeden 2010). Further evidence for a phonetic (rebus) usage of CRUS in the Empire Period is provided by J. D. Hawkins' then of the hieroglyph L. 303, used in the place name Sarissa, as expressing SARA/I (Hawkin 2D). I suggest L. 303 consists of the sign $s a_{5}$ in ligature with CRUS, used with a phonetic value /art, which is later probably found in Hieroglyphic CRUS-RA/I (e.g. KARKAMIŠ A11a §5, Hawkins 2000: 95, 97). It is still unclear how or if this helps with the professional title on the two Nişantepe seals, or indeed with the logograms in KUB 38.12 i 9, 17. Note the translation of LÚ.MEš GUB in 1.9 as "the 'standing'-men" at Taggar-Cohen (2006:

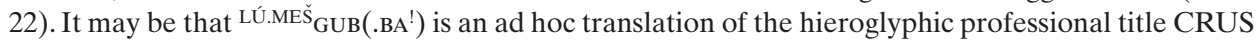
into cuneiform. 
ed from an earlier list in which they stood in the nominative. All these terms are logical objects of the impersonal third plural in para ${ }_{\text {DAB- }} i r^{78}$.

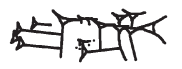

Fig. 3: Photo collation of KUB 38.12 i 17.

M. Darga, the first editor of this tablet, read the logogram in i 17 LÚ.MEŠ ${ }_{\text {GUB.BA }}^{\text {!?7 }}$ S further saw both ${ }^{\text {LÚ.MEŠ }}$ GUB and ${ }^{\text {LÚ.MEŠ }}{ }_{\text {GUB.BA! }}$ as equivalent logograms for the word hilammatti-. ${ }^{\text {LU.MEŚ }}$ GUB and ${ }^{\text {LÚ.MEŠ }}{ }_{\text {GUB.BA! }}$ are likely to refer to the same concept, albeit not the hilammatti-, to which they seem to form a pendant in $1.17^{80}$. They also appear to have different stem-vowels ( ${ }^{\text {LÚ.MEŠ }}{ }_{\text {GUB-an }}$ vs. hilammatti-). Note that the ${ }^{\text {LÚ }}$ GUB-officials are all repeated in the list of hilammatti- officials. It appears the same tasks could be performed as a hilammatti- or as a ${ }^{\mathrm{LU}}$ GUB. It is unclear whether the genitive $\check{S}_{A}$ É GIŠ.KIN.TI in i 17 refers only to the ${ }^{\mathrm{LU}}{ }_{\mathrm{GUB}} \mathrm{BA}$ !. HA officials, or to the hilammatti- and ${ }^{\mathrm{LU}}{ }_{\mathrm{GUB}}$. It is likely that the - $\mathrm{HA}_{\mathrm{A}}$ is in fact the Luwian connective - ha, thus, he ilammatti-officials and the GUB(.BA!)-officials of the House of the Craftspeople“"81.

Even if $\check{S} A$ É GIŠ.KIN.TI applies as a genitive to both the hilammatti- and the GUB(.BA!) officials there are only one scribe and one scribe on wood among all of them. It is thus clear that the staff of the É GIŠ.KIN.TI at Karahna is in no way comparable to what we know of the staff of the É GIŠ.KIN.TI at Hattusa with its 19 scribes and 33 scribes on wood, and all other professions on the preserved surface being most likely associated at least with cultic activity if not with writing: singers of Hurrian, katra-women, priests. Thus the Hittite É GIŠ.KIN.TI does not have to be a scribal institution per se, as indeed it was not one outside of Anatolia, where the Sumerian term giš-kin-ti clearly means simply "craftsperson" or "place of work" $"$. This was just the form it possibly took at Hattusa, using the figure of

78 Pecchioli Daddi (1982: 211) transliterates ${ }^{\text {LÚ.MEŠ }}$ GUB-an-ma-aš-kán from KUB 38.12 i 9 in her section on Lúhilammatta-, but does not include ${ }^{\text {LÚ.MEŠ }}{ }_{\mathrm{GUB}}$ in the index. On the semantic obscurity of the verb phrase parā ep- in cult inventory texts see $\mathrm{HWb}^{2}$ E 82. CHD P 111 translates "selected"; Hazenbos (2003:105,179) "single out, specify", with further literature.

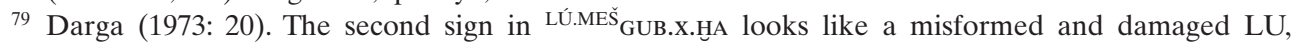
although this makes no sense. Something has gone wrong in the execution of the sign. A photograph was collated in Main Forschungsstelle Hethitologie der Akademie der Wissenschaften und der Literatur in 2007 (fig _ _ ptographs are now available at www.hethiter.net. M. Darga, of course, will have used the original tablet to form her opinion.

80 The transliteration of the logogram in line 17 as LÚ.MEŠ DÉ.DÉ!-za, as found in Pecchioli Daddi (1982: 211), and as translated by Taggar-Cohen (2006: 22) "smith of the temple gear", is not warranted by photo-collation. The translation further shows a confusion of É GIŠ.KIN.TI "House of the Craftspeople" with KIN-ti, the logogram for Hittite aniyatti "(temple) gear, work". Whether the Hittites themselves were guilty of a partially related confusion with regard to these logograms is a different matter (Gordin 2010:159 fn. 6; Weeden 2011b: 87 fn. 406), and currently unverifiable.

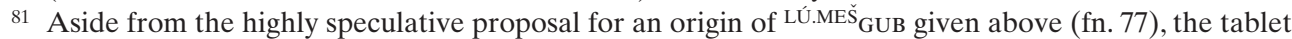
contains several Luwian or Luwoid words (GIŠgastarhaita i 18; hazziwitassis ii 3; pihaimmis iii 19) and exhibits some hesitancy with the use of Hittite enclitic pronouns, e.g. i 9. The i-stem of hilammattamay also be explained as Luwian influence (Rieken 1994 does not include a stem hilammatti-; cf. Hoffner and Melchert 2008: 86).

82 Weeden (2011b: 87 fnn. 398, 405). For the constitution of an Old Akkadian gi ̌̌ -kin - ti see Westenholz (1987:26f.). 
speech that described scribes as being craftspeople. This was a common conceit in the Ancient Near East.

Thus it appears that references to scribal institutions in texts show a somewhat differentiated picture between Hattusa and elsewhere. While at Hattusa we have large, mainly state and temple-related buildings that have been associated with scribal activity, albeit in the $13^{\text {th }}$ century, at Ortaköy and Maşat in the early $14^{\text {th }}$ century it seems more likely that houses belonging to scribes were used for some sort of scribal activity. At Karahna an appendage to the temple known as the É GIŠ.KIN.TI was not occupied by the same staff as at Hattusa. All of this points to a possible uniqueness of the scribal practices at Hattusa as a capital city. We might also note that the tendencies in the provinces correspond to what we expect from scribal schools in much of the Ancient Near East - the É.DUB.BA is a family, domestic or other type of institution incidental to the function of the building which housed it, and the É GIŠ.KIN.TI, "House of the Craftspeople", is a building where people actually do some physical work. It is Hattusa that is the exception.

\section{Bibliography}

Alp, S. 1991: Hethitische Briefe aus Maşat-Höyük. Ankara:Türk Tarih Kurumu.

Alp, S. 1998: Akkadian Names of Some Scribes in the Maşat-Letters. CRRAI 34,47-61.

Archi, A.1966: Trono regale e trono divinizzato nell'Anatolia ittita. SMEA 1,76-120.

Barjamovic, G. 2011: A Historical Geography of Anatolia in the Old Assyrian Colony Period. Copenhagen: Museum Tusculanum Press.

Beal, R. H. 1998: Review of Puhvel, J. Hittite Etymological Dictionary Vol. 3. Berlin and New York (1991). JAOS 118.1,84-86.

Beckman, G. 1983a: Hittite Birth Rituals. Second Revised Edition. StBoT 29. Wiesbaden: Harrassowitz.

Beckman, G. 1983b: Mesopotamians and Mesopotamian Learning at Hattuša. JCS 35, 97-114.

Beckman, G. 1995: Hittite Provincial Administration in Anatolia and Syria. Studia Mediterranea 9, 19-37.

Boehmer, R.M. 1972: Die Kleinfunde von Boğazköy aus den Grabungskampagnen 1931-1939 und 19521969. WVDOG 87. Boğazköy-Hูattuša 7. Berlin: von Zabern.

Borger, R. 2003: Mesopotamisches Zeichenlexikon. AOAT 305. Münster: Ugarit-Verlag.

Charpin, D. 1986: Le clergé d'Ur au siècle d'Hammurabi (XIXe-XVIII siècles av. J.-C.). Genève-Paris: Libraire Droz.

Czichon, R. 2009: Archäologische Forschungen am Oymaağaç Höyük in den Jahren 2005 und 2006. Pecchioli Daddi et alii 2009,25-30 with Plates I-IV.

Darga, M. 1973: Karahna şehri kült-envanteri (Keilschrifturkunden aus Boghazköi XXXVIII 12). Istanbul.

George, A.R. 2005: In Search of the é.dub.ba.a. The ancient Mesopotamian school in literature and reality. Sefati, Y. et alii (eds) "An Experienced Scribe Who Neglects Nothing": Ancient Near Eastern Studies in Honor of Jacob Klein. (Publications of the Samuel Noah Kramer Institute of Assyriology and Ancient Near Eastern Studies. The Faculty of Jewish Studies. Bar-Ilan University). Bethesda, 127-137.

Gordin, S. 2010: The Scribes of the É GIŠ.KIN.TI. Cohen, Y., Gilan, A. and Miller, J.L. (eds) Pax Hethitica. Studies on the Hittites and their Neighbours in Honour of Itamar Singer. StBoT 51. Wiesbaden, 158-177.

Gordin, S. 2011: A Scriptorium of Mahhu(z)zi, MAGNUS.SCRIBA in the Reign of Tudhaliya IV. Süel, A. (ed.) VII. Uluslararası Hititoloji Kongresi Bildirileri, Çorum 25-31 A ğustos, 2008. Ankara, 319-340.

Gurney, O.R. 1940: Hittite Prayers of Mursili II. Annals of Archaeology and Anthropology (Liverpool) $27,1-63$. 
Güterbock H.G. 1944: Zile Yakınında Maşat’tan Gelme Bir Eti Mektubu / Ein hethitischer Brief aus Maşat bei Zile. Ankara Üniversitesi Dil ve Tarih-Coğrafya Fakültesi Dergisi 2, 389-397,399-405.

Güterbock H.G. 1973a: Hittite Hieroglyphic Seal Impressions from Korucutepe. JNES 32, $135-147$.

Güterbock H.G. 1973b: Einige seltene oder schwierige Ideogramme in der Keilschrift von Boğazköy. Neu, E. and Rüster, Chr. (eds) Festschrift Heinrich Otten. 27. Dezember 1973. Wiesbaden, 71-88.

Güterbock H.G. 1975: The Hittite Temple According to Written Sources. CRRAI 20, 125-132.

Hagenbuchner, A. 1989: Die Korrespondenz der Hethiter 1. Die Briefe unter ihren kulturellen, sprachlichen und thematischen Gesichtspunkten. 2. Die Briefe mit Transkription, Übersetzung und Kommentar. TdH 15-16. Heidelberg.

Hawkins, J.D. 2000: Corpus of Hieroglyphic Luwian Inscriptions, Volume. I: Inscriptions of the Iron Age. Berlin.

Hawkins, J.D. 2006: Tudhaliya the Hunter. Hout, Th. P.J. van den (ed.) The Life and Times of Hattušili III and Tuthaliya IV. Proceedings of a Symposium held in Honour of J. de Roos, 12-13 December 2003. Leiden, 50-76.

Hawkins, J.D. 2010: Sarissa, Toponym and Personal Name. Orientalia 79/2, 171-176 with Tables XXIXXII.

Hazenbos, J. 2003: The Organization of the Anatolian Local Cults during the Thirteenth Century B.C. An Appraisal of the Hittite Cult Inventories. CM 21. Leiden: Brill.

Herbordt, S. 2005: Die Prinzen- und Beamtensiegel der hethitischen Grossreichszeit auf Tonbullen aus dem Nişantepe-Archiv in Hattusa, mit Kommentaren zu den Siegelinschriften und Hieroglyphen von J. David Hawkins. Boğazköy-Hattuša XIX. Mainz am Rhein: von Zabern.

Hoffner, H.A. 2009: Letters from the Hittite Kingdom. Edited by G. M. Beckman. Writings from the Ancient World/Society of Biblical Literature 15. Atlanta.

Hoffner, H.A. and Melchert, H.C. 2008: A Grammar of the Hittite Language. Winona Lake: Eisenbrauns.

Hout, Th. van den 2003: De Affaire Tarhunmiya. Brieven van een Hettitische Hofschrijver. Demarée, R. J., Veenhof, K.R. (eds) Zij schreven Geschiedenis. Historische Documenten uit het Oude Nabije Oosten. Leuven and Leiden: Peeters, Ex Oriente Lux, 145-153.

Hout, Th. van den 2007: Some observations on the tablet collection from Maşat Höyük. SMEA 49, 387-398.

Hout, Th. van den 2010: LÚDUB.SAR.GIŠ = "Clerk"? Orientalia 79/2, 255-267.

Houwink ten Cate, Ph.H.J. 1998: The Scribes of the Maşat Letters and the GAL DUB.SAR(.MEŠ) of the Hittite Capital during the Final Phase of the Early Empire Period. Dietrich M., Loretz O. (eds) dubsar anta-men. Studien zur Altorientalistik. Festschrift für Willem H. Ph. Römer zur Vollendung seines 70. Lebensjahres mit Beiträgen von Freunden, Schülern und Kollegen. AOAT 253. Münster, 157-178.

Houwink ten Cate, Ph.H.J. 2003: A New Look at the Outline Tablets of the AN.TAH.-ŠUM ${ }^{\text {SAR }}$ Festival: The Text-Copy VS NF 12.1. Beckman, G.M., Beal, R.H., McMahon, G. (eds) Hittite Studies in Honor of Harry A. Hoffner Jr. on the Occasion of His $65^{\text {th }}$ Birthday. Winona Lake, 205-219.

Imparati, F. 1997: Observations on a Letter from Maşat-Höyük. Archivum Anatolicum 3 (Emin Bilgiç Anı Kitabı), 199-214.

Klinger, J. 1995: Das Corpus der Maşat-Briefe und seine Beziehungen zu den Texten aus Hattuša. ZA 85, 74-108.

Kloekhorst, A. 2008: Etymological Dictionary of the Hittite Inherited Lexicon. Leiden Indo-European Etymological Dictionary. Leiden: Brill.

Marizza, M. 2007: Dignitari ittiti del tempo di Tuthaliya I/II, Arnuwanda I, Tuthaliya III. Eothen 15. Firenze.

Martino, St. de 2005: Hittite Letters from the Time of Tuthaliya I/II, Arnuwanda I and Tuthaliya III. AoF 32, 291-321.

Miller, J.L. 2011: Six Rituals 'Edited' in the Manner of Arusna. In: A. Süel, ed. Acts of the VII ${ }^{\text {th }}$ International Congress of Hittitology, 25-31 August 2008, Çorum, Turkey. Ankara, 497-508.

Miller, J.L. forthcoming: The Palaeography and Orthography of Six Rituals 'Redacted in the Manner of Arusna'. In: E. Devecchi, ed. Proceedings of the International Symposium "Palaeography and Scribal 
Practices in Syro-Palestine and Anatolia in the Late Bronze Age", $17^{\text {th }}-18^{\text {th }}$ Dec. 2009. Nederlands Instituut voor het Nabije Oosten. Leiden.

Müller-Karpe A. 2002: Untersuchungen in Kuşaklı 2001. MDOG 134,331-351.

Müller-Karpe A. 2009: Müller-Karpe A., Recent Research on Hittite Archaeology in the "Upper Land". Pecchioli Daddi et alii 2009,109-117, Plates VII-XII.

Niedorf, Chr. F. 2002: Ein hethitisches Brieffragment aus Alalah. Loretz, O., Metzler, K.A., Schaudig, H. (eds) Ex Mesopotamia et Syria Lux: Festschrift für Manfred Dietrich zu seinem 65. Geburtstag. AOAT 281. Münster, 517-526.

Nougayrol, J. 1956: Le palais royal d'Ugarit 4. Textes accadiens des archives sud (Archives internationales). Mission de Ras Shamra 9. Paris.

Pecchioli Daddi, F. 1982: Mestieri, professioni e dignità nell'Anatolia ittita. Incunabula Graeca 79. Roma.

Pecchioli Daddi et alii 2009: Pecchioli Daddi, F., Torri, G., Corti, C. (eds) Central-North Anatolia in the Hittite Period - New Perspectives in Light of Recent Research. Acts of the International Conference Held at the University of Florence (7-9 February 2007). Studia Asiana 5. Roma.

Puhvel, J.1991: Hittite Etymological Dictionary Vol 3: Words beginning with H.Trends in Linguistic Documentation 5. Berlin - New York.

Rieken, E. 1994: Der Wechsel -a-/-i- in der Stammbildung des hethitischen Nomens. ZVS 107,42-53.

Rieken, E. 1999: Untersuchungen zur nominalen Stammbildung des Hethitischen. StBoT 44. Wiesbaden: Harrassowitz.

Rieken, E. 2009: Die Tontafelfunde aus Kayalıpınar. Pecchioli Daddi et alii 2009, 119-143, Plates XIIIXVIII.

Robson, E. 2001. The tablet house: a scribal school in Old Babylonian Nippur. Revue d'Assyriologie et d'Archéologie Orientale 95,39-66.

Schwemer, D. 2004: Von Tahurpa nach Hattusa. Überlegungen zu den ersten Tagen des AN.DAHु.-ŠUMFestes, Hutter, M. and Hutter-Braunsar, S. (eds) Offizielle Religion, lokale Kulte und individuelle Religiosität. Akten des religionsgeschichtlichen Symposiums „Kleinasiens und angrenzende Gebiete vom Beginn des 2. bis zur Mitte des 1. Jahrhunderts v. Chr." (Bonn, 20.-22. Februar 2003). AOAT 318. Münster, 395-412.

Sommer, F. 1932:Die Ahhijavā-Urkunden. München: Bayerische Akademie der Wissenschaften.

Süel,A. 1995: Ortaköy'ün Hitit Çağındaki Adı. Belleten 59, 271-283.

Süel, A. 2008: Hitit Devleti'nin bir diğer başkenti: Şapinuva. Tarhan, T., Tibet, A., Konyar, E. (eds) Muhibbe Darga Arma ğanı. Istanbul: Sadberk Hanım Müzesi Yayınları, 457-474.

Süel, A. 2009: Another Capital of Hittite State: Šapinuwa. Pecchioli Daddi et alii 2009, 193-206, Plates XIX-XXIII.

Süel, A. and Soysal, O. 2003: A Practical Vocabulary from Ortaköy. Beckman, G., Beal, R., McMahon, G. (eds) Hittite Studies in Honor of Harry A. Hoffner Jr. on the Occasion of his $65^{\text {th }}$ Birthday. Winona Lake, 349-365.

Süel, A. and Soysal, O. 2007: The Hattian-Hittite Foundation Rituals from Ortaköy (I). Fragments to CTH 725 "Rituel Bilingue de Consécration d'un Temple". Anatolica 33,1-22.

Süel, M. 2008: Ortaköy-Şapinuva'da bulunan bir grup kalıp. Tarhan, T., Tibet, A., Konyar, E. (eds) Muhibbe Darga Armağanı. Istanbul: Sadberk Hanım Müzesi Yayınları, 475-484.

Tanret, M. 2002: Per aspera ad astra: l'apprentissage du cunéiforme à Sippar-Amnānum pendant la période paléobabylonienne tardive. Mesopotamian History and Environment, Series III. Texts 1. Ghent: University of Ghent.

Taş, İ. and Weeden, M. 2010: A Stele of Prince Anaziti in the Yozgat Museum. Journal of the American Oriental Society 130.3,349-359.

Torri, G. 2008: The Scribes of the House on the Slope. Archi, A. and Francia, R. VI Congresso Internazionale di Ittitologia, Roma, 5-9 settembre 2005. SMEA 50,771-782.

Torri, G. 2009: The Old Hittite Textual Tradition in the „Haus am Hang“. Pecchioli Daddi, F., Torri, G. and Corti, C. (eds), Central-North Anatolia in the Hittite Period. New Perspectives in Light of Recent Research. Acts of the International Conference Held at the University of Florence (7-9 February 2007). Studia Asiana 5. Rome, 207-222. 
Volk, K. 2000: Edubba'a und Edubba'a-Literatur: Rätsel und Lösungen. ZA 90,1-30.

Waal, W. 2010: The Source as Object. Studies in Hittite Diplomatics. PhD Dissertation. University of Leiden.

Weeden, M. 2010: A Hittite Seal from Kaman-Kalehöyük. Singer, I. (ed.) ipamati kistamati pari tumatimis. Luwian and Hittite Studies Presented to J. David Hawkins on the Occasion of his $70^{\text {th }}$ Birthday. Tel Aviv, 249-255.

Weeden, M. 2011a: Adapting to New Contexts: Cuneiform in Anatolia. Radner, K. and Robson, E. $O x$ ford Handbook of Cuneiform Culture. Oxford: Oxford University Press, 597-617.

Weeden, M. 2011b: Hittite Logograms and Hittite Scholarship. StBoT 54. Wiesbaden: Harrassowitz.

Wilhelm, G. 1995: Die Tontafelfunde der 2. Ausgrabungskampagne 1994 in Kuşaklı. MDOG 127,37-42.

Westenholz, A. 1987: Old Sumerian and Akkadian Texts in Philadelphia. Part Two: The 'Akkadian Texts', the Enlilemaba Texts and the Onion Archive. Carsten Niebuhr Institute of Ancient Near Eastern Studies. University of Copenhagen 1987. Copenhagen.

Wiseman, D.J. 1953: The Alalakh Tablets. British School of Archaeology at Ankara. London.

Yoshida, D. 1994: Hittite Seals with Hieroglyphic Inscriptions from Kaman-Kalehöyük (Japanese). Anatolian Archaeological Studies: Kaman-Kalehöyük 3,107-114.

Yoshida, D. 1999: Hethitische Hieroglyphensiegel aus Kaman-Kalehöyük, in: Mikasa, T. (ed.), Essays on Ancient Anatolia, (BMECCJ 11), 183-197.

Yoshida, D. 2006: 'Mittelhethitische' Siegelfunde von Kaman-Kalehöyük, in: Anatolian Archeological Studies Kaman-Kalehöyük 15, Tokyo, 151-162.

\author{
Mark Weeden \\ School of Oriental and African Studies \\ GB - London WC1H 0XG. \\ mw41@soas.ac.uk
}

